\title{
Transparancy and Accountability Contribution Toward Sustainability of Banking Sector in Indonesia
}

\author{
Helma Malini \\ Universitas Tanjungpura \\ Jalan Prof. Hadari Nawawi Pontianak, Kalimantan Barat, Indonesia \\ helma.malini@untan.ac.id
}

\begin{abstract}
The board of directors, administrators, and top management personnel all play a role in establishing strategies, setting goals, and assigning duties to implementers. One of the primary goals of corporate governance is to increase shareholder value. On this basis, it can be argued that corporate governance is a critical component of any business's long-term viability. The goal of the study was to see how transparency and accountability affected the banking sector's long-term viability. The study was guided by three theories: agency theory, stewardship theory, and stakeholder's theory, all of which provide important information on corporate governance processes and how different stakeholders' interests are addressed. This study employs a quantitative research methodology. It is used to quantify a problem in quantitative research by generating numerical data or data that can be turned into useable statistics. Transparency, accountability, justice, and responsibility, according to the study, all have a substantial impact on the banking industry's long-term viability. The study suggests that transparency and accountability have a favorable and considerable impact on the banking industry's long-term viability. The result suggesting that all Indonesian banks' management should strictly enforce openness in all operations and activities conducted by workers in order to achieve sustainability.
\end{abstract}

Keywords: Indonesia, Banking Industry, Transparency, Accountability, Sustainability

\section{INTRODUCTION}

For the first time since the financial crisis of 2007, global banking has begun to generate overall profits, and it is critical that greater public disclosure be implemented. Within derivative markets, secrecy permits corporations to avoid disclosure and build up concealed risk, making it difficult for regulators to carry out their duties. Continued inefficiency at a bank could be taking crucial resources that a bank needs to thrive. However, relying primarily on cost-cutting is not a long-term winning strategy. A balanced strategy is critical to a bank's operations and profitability, as it allows it to not only enhance operating efficiency but also upgrade its capabilities to respond to market needs and plan for the future. As a result, bettering the bank's management and corporate governance is essential.

Corporate governance, or what is commonly referred to as Good Corporate Governance (GCG), has been practiced for a long time. GCG is crucial in the establishment of a company with the goal of increasing the income and welfare of the company's owners and shareholders, as well as employees. GCG can assist the firm in becoming more developed by delegating decision-making authority to stakeholders, allowing the company management to focus on generating profits for the company's owners and shareholders. The concepts and metrics for strong corporate governance are the same in every sector; the difference is in how they are applied. Because banking firms deal with people's trust and the Indonesian economy, requirements implementing effective corporate governance in the banking sector has been extremely difficult [1], [2]. [3]

Some of the reasons why Good Corporate Governance should be implemented in banking organizations include maintaining honesty, dedication, commitment, and establishing public trust as a business that contributes to a country's economy. Good corporate governance establishes a professional framework that specifies the interaction between the company's owners, managers, shareholders, and stakeholders. Each role has its own set of tasks that must be completed with accountability and responsibility while working for the same aim of high profit [4].

Credit, operational, market, and liquidity risk are all major concerns for banks. Banks have well-built risk management infrastructures and are expected to obey government rules since they are exposed to a variety of hazards. Overexposure to risk can result in bank failure, affecting millions of people, due to the massive size of some institutions. Governments can better regulate banks by recognizing the risks they face. This will encourage responsible management and decision-making. [5].

Investors' decisions are influenced by a bank's capacity to manage risk. Even if a bank generates significant revenues, poor risk management might 
result in lesser profitability due to loan losses. Value investors are more willing to put their money into a bank that can generate profits while posing little risk of losing money. Not only for effective policy, but also for democratic legitimacy, a bank that is transparent, accountable, and well-governed is required. Not only to strengthen accountability, but also to correct the significant deficiencies that have been exposed, more clarity in the dissemination of public information and improvements to internal controls inside banks are required [6].

A more resilient and long-term global financial system, which entails establishing accountability and transparency norms. If the banking sector has a more trustworthy information system about the distribution of risky loan returns, we consider it to be more transparent. As previously stated, increased transparency does not always imply a reduction in exogenous return uncertainty. Instead, the reliability of a publicly observable signal that is correlated with the concept of transparency is what we're talking about [7], [8].

Good corporate governance is a method of fostering a trusting, transparent, and accountable business climate that encourages investment, financial stability, and long-term economic success. Corporate governance can be defined as a process and framework for directing and managing a company's affairs with the ultimate goal or objective of attaining shareholders' long-term goals. Good corporate governance ethical values, according to [9], include responsibility, accountability, fairness, and transparency, with the main goal of increasing a firm's value and benefits, reducing financial and business risks, preventing dishonest and fraudulent operational activities, refusing unethical work behavior, and increasing confidence levels of shareholders [10].

Sustainable banking does not yet have a clear definition [9]. At this point, it is commonly accepted that sustainable banking entails conducting banking operations and business activities while taking into account the environmental and social consequences of those actions. Both human resources, expenses, opportunities, and risk exposures) and their activities relating to outward interactions with their clients and the types of projects they sponsor execute sustainable banking. their internal daily operations (in terms of how they manage their physical branches/locations [1], [11].

Some studies in the banking sector have looked at the perceptions of internal and external stakeholders
[12]-[15] or the disclosure of sustainable information through bank publication reports [16] and the motivations for implementation [17], However, there are still a few research looking into the influence of implementing sustainable banking on bank performance. Sustainable issues are still a concern in banking sector study, which tends to focus on the use of information technology innovation and improving the quality of financial services themselves, so it's a fascinating subject to investigate further.

In practice, there is still a discussion about whether sustainable banking makes a good contribution to the improvement of financial or nonfinancial institutions. Because the financial sector is typically profit-driven, financial success is critical to ensuring that the business survives among the competition. Nonfinancial performance issues, such as social and environmental issues, on the other hand, in their business activities, they also boost banking performance.

The aim of this research was to observe the effect of transparency and accountability contribution toward sustainability of banking sector in Indonesia. Sustainable banking practice are crucial since the adoption was influenced by contextual factors (bank-specific factors), so that bank corporate governance affecting process of going to sustainability. The findings of this study may help to support sustainable banking practices, not only as a short-term financial investment as cash outflow, but also as a policy discretion that will have an impact on bank performance in the long run. In terms of regulation, this research will support the roadmap of sustainable finance for financial institutions in Indonesia, as stated in The Financial Services Authority's regulation (OJK).

\section{LITERATURE REVIEW}

Companies are trying for more sustainable performance in today's business world by combining economic, social, and environmental policies into their operations. In this regard, corporate governance plays a critical role in making successful decisions about proactive sustainability policies [11], [18], [19].

Good governance is also linked to greater social and environmental performance monitoring, so that illegal and socially unacceptable behaviors are avoided in order to retain a company's market image. Corporate governance elements (such as board composition, CEO duality, and board size) may have a significant impact on sustainability performance. In a similar 
spirit, [18] argued that more disciplined workers are more productive.

Boards with a higher ratio of independent directors have better sustainability performance (in terms of board meeting attendance). Furthermore, as compared to their counterparts, high sustainable enterprises have more responsible boards whose incentives are tightly tied to economically, ecologically, and socially related activities [20]. Sound governance, according to $\mathrm{A}[21]$, is most likely to have a beneficial impact on sustainability performance. In addition, in the boardrooms of companies, governance and sustainability are merging through the "triple bottom line" (Burgessb et al., 2017). The governance mechanism has the potential to connect economic, social, and environmental aspects, resulting in longterm value creation [23].

Stakeholder theory, in particular, may explain the link between business governance and long-term viability. in such a way that "the corporate governance structure will ensure the preservation of by integrating economic, social, and environmental concerns, stakeholders' interests are served. into the operations and plans of the corporation [4].

[24] conducted a research in Australia on sustainability accounting and reporting. The study used a desk review method, in which pertinent data and previous studies on sustainability accounting and reporting were scrutinized. The primary result was that solid corporate governance standards are the foundation upon which investors and lenders place their trust, and that transparency is essential if enterprises are to be long-term sustainable. However, the study was conducted in Australia rather than Kenya, leaving a contextual gap that the current study would attempt to solve.

[25] examined how corporate governance affects performance using the example of banks. The study specifically looked at the difficulties and solutions to corporate governance issues in the banking sector. The research was conducted in France, with the goal of examining and gathering important secondary data on corporate governance variables such as board size, board composition, and CEO duality. It was discovered that the most important issue facing commercial banks is openness in terms of their operations and how they are reported in reports.

A number of significant empirical studies on sustainable banking have been carried out. Handajani et al. (2019) investigated bank introduction with environmental issues in various state-owned banks and discovered that they have already used sustainable banking principles such as green product, green customer, and green operational in their operations. Akteret al. (2018) conducted another study on numerous commercial banks in Bangladesh on their bank sustainability reports, and they discovered that banks reported more economic and social indicators in their sustainability reports than environmental issues. In comparison to the previous year, the majority of banks also disclosed economic indicators connected to climate change and the financial implications of climate change.

Awino (2014) discovered strong evidence that green banking as a sustainable program is having a positive impact on financial performance of the bank, so that the government should make an environmental conservation policy that should be implemented. Based on previous study conducted on the sustainable banking around the area of transparency showed that banking directly and indirectly influence on performance since it is an endeavor by a financial institution to attain sustainability. Implementing sustainable concerns in banking business operations, according to certain studies, will have an impact on bank performance, both financial and non-financial. This skepticism concerning the long-term impact of implementation. This skepticism of the impact of longterm adoption on commercial banks, such as increased expenditures that interrupt typical bank operations, is reflected in the report. Thus, this research trying to reflect on the aspect of particular Good Corporate Governance (transparency and accountability) that will effect on bank sustainability.

\section{METHODOLOGY}

The type of research used in this study is causal research, which aims to determine the scope and nature of cause-and-effect interactions. In causal research, the researcher might look at how independent factors interact with one another and how that influences the dependent variable. This study employs a quantitative research methodology. It is used to quantify a problem in quantitative research by generating numerical data or data that can be turned into useable statistics.

Sources of Data

The investigation relied on secondary data from banking institutions. The secondary data is in the form of annual reports and financial reports published on the internet by banking companies listed on the Indonesia Stock Exchange (IDX) from 2015 to 2019. 
1. Selected banking company's financial report from 2015 to 2019 (32 companies)

2. Data on the actions (meetings) of the Board of Commissioners of each selected banking company from 2015 to 2019 is available in the annual report of banking firms.

3. From 2015 to 2019, historical data on the size of the Board of Directors of each selected banking company was published in the annual report of banking businesses.

\section{Research Variables}

Independent Variable

An independent variable is one that has no bearing on the other variables in the study. The activities (meetings) of the Board of Commissioners, the size of the Board of Directors, the size of the Board of Independent Commissioners, and the size of the Audit Committee are all independent variables in this study. The variables selected based on the reasons that Board of Commissioners activity (meetings and size) will influence the performance and sustainability of the bank.

Dependent Variable

In research, a dependent variable is a variable that is impacted by an independent variable. Firm Performance is the research's dependent variable.

Control Variable

A control variable is one that remains constant and unmodified throughout the study. Net Interest Margin and Firm Size are the study's control variables (natural logaritm of Total Asset).

Analysis Methods

The data from this study will be evaluated using EViews 8's Multiple Regression Analysis. In econometric, Eviews is a statistical software application for processing and analyzing cross-section and time series data. Identifying theories or hypotheses, establishing mathematical models of theories, specifying statistical models, collecting data, estimating parameters using econometric models, and testing hypotheses are all part of the econometric technique.

In multiple regression studies, these steps are necessary to satisfy the linear assumption and get the Best Linear Unbiased Estimators (BLUE). To discover the most effective model for estimating the outcome of this study, the best model among the Common Effect Model, Fixed Effect Model, and Random Effect Model will be reviewed and compared.

Model I
$\mathrm{Y} 1=\mathrm{a}+\beta$ 1.X1it $+\beta 2 . \mathrm{X} 2 \mathrm{it}+\beta 3 . \mathrm{X} 3 \mathrm{it}+\beta 4 . \mathrm{X} 4 \mathrm{it}+\beta$

5.X5it $+\beta$ 6.X6it $+\varepsilon$ Where:

$\mathrm{a}=$ Constanta

$\beta 1, \beta 2, \beta 3, \beta 4, \beta 5, \beta 6=$ Regression coefficient Model II

$\mathrm{Y} 2=\mathrm{a}+\beta$ 1.X1it $+\beta 2 . \mathrm{X} 2 \mathrm{it}+\beta 3$.X3it $+\beta 4 . \mathrm{X} 4 \mathrm{it}+\beta$

$5 . X 5 i t+\beta 6 . X 6$ it $+\varepsilon$

Therefore, from the assumption possibilities stated,

the model of regression is divided into these three

models:

Common Effect Model

$Y i t=\alpha+X i t \beta+$ uit $; i=1,2, \ldots, n ; t=1,2, \ldots, n$

Fixed Effect Model

$Y i t=\alpha i+X i t \beta+u i t ; i=1,2, \ldots, n ; t=1,2, \ldots, n$ Random Effect Model

$Y i t=\alpha 0+X i t \beta+(\varepsilon i+\gamma i) ; i=1,2, \ldots, n ; t=1,2$, $\ldots, n$

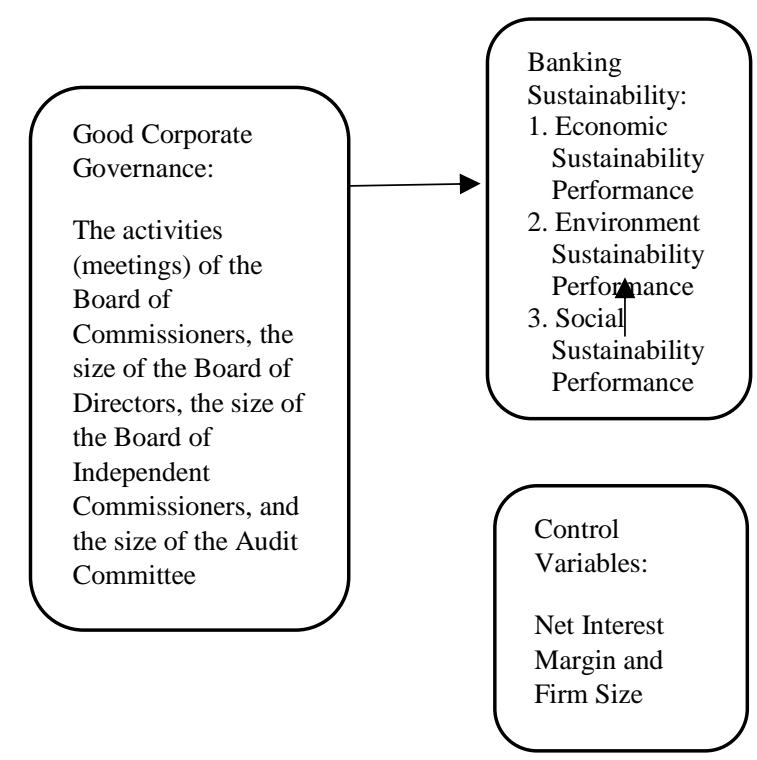

Figure 1. Research Framework

IV. RESULT AND DISCUSSION

Table 1. Descriptive Statistic

\begin{tabular}{lcccccccc}
\hline & Y1 & Y2 & X1 & X2 & X3 & X4 & X5 & X6 \\
\hline Mean & 0.14 & 1.53 & 14.41 & 6.96 & 2.97 & 3.9 & 4.94 & 31.54 \\
\hline Median & 0.07 & 1.24 & 10 & 7 & 3 & 4 & 4.85 & 31.31 \\
\hline $\begin{array}{l}\text { Max- } \\
\text { imum }\end{array}$ & 3.71 & 4.99 & 60 & 12 & 6 & 7 & 9.3 & 34.89 \\
\hline $\begin{array}{l}\text { Min- } \\
\text { imum }\end{array}$ & -1.12 & 0 & 2 & 3 & 1 & 3 & 0.39 & 28.35 \\
\hline $\begin{array}{l}\text { Std. } \\
\text { Dev. }\end{array}$ & 0.34 & 1.04 & 12.63 & 2.56 & 1.04 & 1.06 & 1.67 & 1.71 \\
\hline $\begin{array}{l}\text { Skew- } \\
\text { ness }\end{array}$ & 7.15 & 1.20 & 1.81 & 0.31 & 0.66 & 1.12 & -0.06 & 0.12 \\
\hline $\begin{array}{l}\text { Kur- } \\
\text { tosis }\end{array}$ & 78.93 & 4.14 & 5.38 & 1.97 & 2.67 & 3.51 & 3.29 & 2.12 \\
\hline Sum & 22.08 & 244.51 & 2305 & 1114 & 475 & 624 & 789.8 & 5046.30 \\
\hline
\end{tabular}




\begin{tabular}{lllllllll}
\hline Obser- & 160 & 160 & 160 & 160 & 160 & 160 & 160 & 160
\end{tabular}

Source: Eviews 8.0 (Processed Data)

According to table 4.1.1, there are 160 total observations, 32 cross section data, and a 5-year timeframe. Tobin'Q is represented by the dependent variable $\mathrm{Y} 1$, which has a minimum and maximum value of -1.12 and 3.71 , respectively. These figures indicate that the standard deviation of the companies' Tobin'Q has a minimum of -1.12 and a maximum of 3.71. Price-to-Book Value (PBV) is the second dependent variable, with a minimum and maximum value of 0 and 4.99, respectively. The standard deviation of the companies' PBV has a minimum and maximum value of 0 point and 4.99 point, respectively.

The first independent variable, $\mathrm{X} 1$, represents the Board of Commissioners' activity (meetings) from 2015 to 2019. The value was calculated using the number of Board of Commissioners meetings listed in each company's annual report. It has a value of 2 at the lowest end and 60 at the highest end. During the period 2015-2019, the second independent variable X2 represents the size of the Board of Directors. The number of Board of Directors members listed in each company's annual report was used to calculate the value. The third independent variable, $\mathrm{X} 3$, represents the number of Commissioners on the Board of Independence from 2015 to 2019. The number of Independence Commissioners listed in each company's annual report was used to calculate the figure. Its minimum and maximum values are 1 and 6 , respectively.

Tabel 2. Common Effect Model I

\begin{tabular}{ccccc}
\hline Variable & Coefficient & $\begin{array}{c}\text { Std. } \\
\text { Error }\end{array}$ & t-Statistic & Prob. \\
\hline $\mathrm{C}$ & 0.0014 & 1.1837 & 0.0012 & 0.9991 \\
\hline $\mathrm{X} 1$ & -0.0027 & 0.0026 & -1.0397 & 0.3001 \\
\hline $\mathrm{X} 2$ & 0.0282 & 0.0256 & 1.1006 & 0.2728 \\
\hline $\mathrm{X} 3$ & -0.0414 & 0.0410 & -1.0086 & 0.3148 \\
\hline $\mathrm{X} 4$ & 0.0356 & 0.0298 & 1.1955 & 0.2338 \\
\hline $\mathrm{X} 5$ & 0.0458 & 0.0166 & 2.7625 & 0.0064 \\
\hline $\mathrm{X} 6$ & -0.0083 & 0.0438 & -0.1904 & 0.8492 \\
\hline Source: Eviews 8.0 (Processed Data) & &
\end{tabular}

The table reveals that the impact of Board of Commissioners activities (meetings) on Tobin'Q is minor, as the probability value is larger than the $\mathrm{p}$ value ( 0.05 or 5 percent). The coefficient of X1 indicates that for every 1-point change in X1, there will be a 0.0027 -point change in Tobin'Q in the opposite direction, which is referred to as a negative relationship. The findings of this study show that activities (meetings) are beneficial.
Table 3. Model Summary

\begin{tabular}{ccccc}
\hline Model & $\mathrm{R}$ & $\begin{array}{l}\mathrm{R} \\
\text { Square }\end{array}$ & $\begin{array}{l}\text { Adjusted } \\
\text { R Square }\end{array}$ & $\begin{array}{c}\text { Std. Error of } \\
\text { the Estimate }\end{array}$ \\
\hline 1 & $.929 \mathrm{a}$ & .862 & .859 & 80201 \\
\hline
\end{tabular}

a. Predictors: (Constant), Accountability, Transparency

Table 4. Analysis of Variance

\begin{tabular}{lccccc}
\hline & $\begin{array}{c}\text { Sum of } \\
\text { Squares }\end{array}$ & df & $\begin{array}{c}\text { Mean } \\
\text { Square }\end{array}$ & F & Sig. \\
\hline Regression & 656.940 & 4 & 164.235 & 255.331 & $.000 \mathrm{~b}$ \\
\hline Residual & 104.845 & 163 & .643 & & \\
\hline Total & 761.786 & 167 & & & \\
\hline
\end{tabular}

a. Dependent Variable: Sustainability of the banking sector

b. Predictors: (Constant), Accountability, Transparency

Table 5. Regression Coefficients

\begin{tabular}{lccccc}
\hline & $\begin{array}{c}\text { Unstan- } \\
\text { dar- } \\
\text { dized }\end{array}$ & $\begin{array}{c}\text { Coef- } \\
\text { fi- } \\
\text { cients }\end{array}$ & $\begin{array}{c}\text { Standar } \\
\text {-dized } \\
\text { Coeffici } \\
\text {-ents }\end{array}$ & & \\
\hline & $\mathrm{B}$ & $\begin{array}{c}\text { Std. } \\
\text { Error }\end{array}$ & Beta & $\mathrm{t}$ & Sig. \\
\hline (Constant) & 7.323 & 3.283 & & 2.231 & .027 \\
\hline $\begin{array}{l}\text { Trans- } \\
\text { parency }\end{array}$ & .151 & .058 & .298 & 2.589 & .011 \\
\hline $\begin{array}{l}\text { Accoun- } \\
\text { tability }\end{array}$ & .177 & .063 & .277 & 2.805 & 001 \\
\hline
\end{tabular}

a. Dependent Variable: Sustainability of the banking sector

From Table 3, the following equation is formulated;

$\mathrm{Y}=7.323+.151 \mathrm{X} 1+.177 \mathrm{X} 2$ Where:

$\mathrm{Y}=$ Sustainability of commercial banks;

$\mathrm{X} 1$ = Transparency;

$\mathrm{X} 2=$ Accountability

When all of the factors are maintained constant, the banking industry's sustainability is estimated to be 7.323. With all other conditions held constant, a unit increase in transparency would result in a 15.1 percent rise in commercial bank sustainability. With other factors held unchanged, a unit change in accountability would result in a $17.7 \%$ difference in commercial bank sustainability.

The study found that transparency had a p-value of 0.011 , which is less than 0.05 , indicating that it has a substantial impact on the banking industry's longterm viability. Accountability has a significant impact on sustainability $(\mathrm{p}=0.0010 .05)$. Transparency refers to the bank's open, transparent, and timely disclosure of all relevant information about its strategy, assessments, and policy decisions, as well as its 
procedures, to the saver and markets. Transparency is now considered vital by most banking including in Indonesia [16], [26], [27]

Table 6. Fixed Effect Model II

\begin{tabular}{ccccc}
\hline Variable & Coefficient & Std. Error & t-Statistic & Prob. \\
\hline $\mathrm{C}$ & -2.3993 & 5.2417 & -0.4577 & 0.6480 \\
\hline $\mathrm{X} 1$ & -0.0157 & 0.0043 & -3.6202 & 0.0004 \\
\hline $\mathrm{X} 2$ & 0.0183 & 0.0346 & 0.5296 & 0.5973 \\
\hline $\mathrm{X} 3$ & 0.0151 & 0.0560 & 0.2692 & 0.7882 \\
\hline $\mathrm{X} 4$ & 0.0967 & 0.0468 & 2.0674 & 0.0408 \\
\hline $\mathrm{X} 5$ & -0.0869 & 0.0549 & -1.5816 & 0.1163 \\
\hline $\mathrm{X} 6$ & 0.0838 & 0.1626 & 0.5155 & 0.6071 \\
\hline
\end{tabular}

Source: Eviews 8.0 (Processed Data)

Because it no longer treats all companies as the same, the Fixed Effect Model produces a different result than the Common Effect Model. As a result, each organization has a unique equation, and in this example, a unique intercept point. This method employed the same OLS method as before, but it provided a better explanation for the real market condition, as each banking should have its own management system and organizational structure.

A bank's organizational structure normally contains one top executive who is assisted by additional senior staff members. The many functions in a retail bank, ranging from electronic banking services to customer service and managers of specific divisions tend to force a bank caught up in an ineffective management. Bank management emphasizes change (internal and external), but in the real world, it is difficult to adapt changes to market conditions [28]. As a result, banks must restructure and reorganize their management structures in light of the new regulations. Banks require application as well as the ability to adapt to changing and uncertain business and financial situations where eventually it will be led bank to achieve sustainability.

The findings of this study back up previous research findings that the combination of transparency and accountability can play an effective role in encouraging bank sustainability. Nonetheless, this result did not provide sufficient support for [29] findings, which stated that transparency and accountability contributed to the bank's sustainability. The findings of this study had theoretical, practical, and policy implications. In terms of theoretical implications, the Legitimacy Theory was argued in sustainable banking practice. The use of sustainable business by a bank demonstrated an attempt to gain operational legitimacy by meeting the expectations of stakeholders or regulations regarding the implementation of sustainable in banking business. It was expected that banks would not only focus on economic gain in their business policies, but also on social aspects and the impact on the environment by being transparent and accountable.

\section{CONCLUSION}

Banking industries in Indonesia is committed to sustainability, but they need certain success elements in place to reap the full rewards of their efforts. Despite this development, all banks agree that more can be done to improve on their present sustainable banking achievements. The majority of banks stated that sustainability was well-integrated into their business plans. However, in order for banks to have the greatest positive impact on Indonesia's long-term growth, they must include sustainable banking practices.

The more meetings held by the Boards of Commissioners of financial businesses, the worse their performance is, forcing them to look for, examine, and discuss the causes of the company's fall in terms of sustainability. The size of the Board of Directors has a positive but small effect on Tobin'Q in Model I. It shows that, in Model I, increasing the number of Board of Directors will likewise raise the Tobin'Q of a banking company's sustainability. Meanwhile, under Model II, the size of the Board of Directors has a negligible effect on PBV. It shows that increasing the number of Board of Directors on Model II lowers the banking company's PBV. The size of the Board of Independent Commissioners has a favorable impact on the long-term viability of the banking system. Depending on the measurement used, the result has varying degrees of relevance. The number of the Board of Independent Commissioners has a positive but small effect on Tobin'Q in Model I. Meanwhile, the size of the Board of Independent Commissioners has a large beneficial effect on PBV in Model II.

As a result, the size of the Board of Independent Commissioners has a beneficial impact on banking sustainability, whether it is large or not. The number of independent commissioners on the Board of Commissioners increases banking sustainability because the Board of Independent Commissioners is expected to minimize conflict of interest among board members in order to protect minority shareholders 
interests and keep everything in balance and sound condition, which will also reduce agency problems within the company. The size of the Audit Committee has a negligible impact on the banking industry's longterm viability. Both models produce the same result. The larger the Audit Committee, the lower the banking sustainability. A larger Audit Committee will be filled with diverse skills and knowledge of its large counterpart, affecting Audit Committee quality as Audit Committees encourage more conservative detailed reporting, lowering banking sustainability financially.

The fact-based findings suggest a fresh beginning in the theorizing process, in which theories must attempt to explain not just the impact of corporate governance on sustainability, but also which aspects of sustainability may be most affected. The most important consequence for practitioners is that it may be possible to garner support for sustainable activities by implementing certain corporate governance structures. The findings also help to the continuing standard-setting process, particularly in relation to the in-depth reassessment of the economic aspects of sustainability under the new GCG framework. This research's practical application was beneficial for bank management in disclosing sustainability issues in corporate reports, such as economic, social, and environmental indicators, in order to provide transparency to external parties and relevant stakeholders.

Adoption of sustainability in the banking industry was done to reduce financial, as well as social and environmental risks, so that sustainability should become a strategic issue in the banking industry. The implication of this research was to support regulations on the implementation of pro-environmental policies, such as sustainable finance in banking activity, in order to support sustainable development.

\section{REFERENCES}

[1] C. Chidoko and N. Mashavira, "An analysis of corporate governance in the banking sector of Zimbabwe," Humanit. Soc. Sci. Lett., vol. 2, no. 3, pp. 174-180, 2014.

[2] A. Ayunitha, H. W. Sulastri, M. I. Fauzi, M. A. P. Sakti, and N. M. Nugraha, "Does the Good Corporate Governance Approach Affect Agency Cost," Solid State Technol., vol. 63, no. 4, pp. 3760-3770, 2020.

[3] A. Ayunitha, H. W. Sulastri, M. I. Fauzi, M. A.
P. Sakti, and N. M. Nugraha, "Does the Good Corporate Governance Approach Affect Agency Cost," Solid State Technol., vol. 63, no. 4, pp. 3760-3770.

[4] M. Krenn, "Decoupling as a Sustainable Firm Response to Pressures for Convergence and Divergence in Corporate Governance: The Case of Codes of Good Corporate Governance.," J. Manag. Policy Pract., vol. 15, no. 4, 2014.

[5] H. Malini and A. N. Putri, "Competitiveness and Market Concentration of Islamic Banking Industry: A Comparison Study between Indonesia and Malaysia," Sriwij. Int. J. Dyn. Econ. Bus., vol. 4, no. 3, pp. 175-190, 2020.

[6] A. Price and H. H. Shawa, "Risk and risk management in project-related finance," 1997.

[7] D. D. Sharma and A. Blomstermo, "The internationalization process of born globals: a network view," Int. Bus. Rev., vol. 12, no. 6, pp. 739-753, 2003.

[8] S. O. Ashamu and J. Abiola, "The impact of global financial crisis on banking sector in Nigeria," Br. J. Arts Soc. Sci., vol. 4, no. 2, pp. 251-257.

[9] E. Manurung, E. Effrida, and A. J. Gondowonto, "Effect of financial performance, good corporate governance and corporate size on corporate value in food and beverages," Int. J. Econ. Financ. Issues, vol. 9, no. 6, p. 100, 2019.

[10] F. Dialysa, "Green banking: One effort to achieve the principle of good corporate governance (GCG)," in First International Conference on Economics and Banking (ICEB15), 2015, pp. 128-132.

[11] K. Kumar and A. Prakash, "Managing sustainability in banking: extent of sustainable banking adaptations of banking sector in India," Environ. Dev. Sustain., pp. 1-19, 2019.

[12] B. Nyagadza, E. M. Kadembo, and A. Makasi, “Exploring internal stakeholders' emotional attachment \& corporate brand perceptions through corporate storytelling for branding," Cogent Bus. Manag., vol. 7, no. 1, p. 1816254, 2020.

[13] K. M. De Silva and C. S. D. S. Lokuwaduge, "Impact of corporate social responsibility practices on employee commitment," Soc. Responsib. J., 2019.

[14] H. Z. Khan, S. Bose, A. T. Mollik, and H. 
Harun, “'Green washing' or 'authentic effort'? An empirical investigation of the quality of sustainability reporting by banks," Accounting, Audit. Account. J., 2020.

[15] N. Mushtaq, "Paramount role of corporate social responsibility in retaining employees and corporate reputation: an extract from Pakistan's banking sector," J. Bus. Financ., vol. 1, no. 3, pp. 126-138, 2013.

[16] R. Hosna, "The Participation Of The Student's Parents Association In Increasing Students Learning Motivation In Islamic Religious Education Lesson At Sdit As Syafi'iyah Ponorogo Indonesia," Turkish J. Comput. Math. Educ., vol. 12, no. 7, pp. 1931-1937, 2021.

[17] V. Indrajati, Y. Yuvita, N. A. Putri, F. O. Rismawati, and D. M. Puspitasari, "Determinants of Financial Distress Rural Bank in Indonesia: A Logit Approach," Solid State Technol., vol. 63, no. 3, pp. 5069-5075, 2020.

[18] G. Hubbard, "The quality of the sustainability reports of large international companies: An analysis," Int. J. Manag., vol. 28, no. 3, p. 824, 2011.

[19] A. L. Kiesnere and R. J. Baumgartner, "Sustainability management in practice: Organizational change for sustainability in smaller large-sized companies in Austria," Sustainability, vol. 11, no. 3, p. 572, 2019.

[20] A. E. Jeffers, S. Romero, and L. A. DeGaetano, "Is It Time for Companies to Capitalize on Sustainability?," CPA J., vol. 84 , no. 3, p. 6 , 014.

[21] R. Y. J. Siew, M. C. A. Balatbat, and D. G. Carmichael, "The relationship between sustainability practices and financial performance of construction companies," Smart Sustain. Built Environ., 2013.

[22] J. Burgess, R. Cameron, S. Dhakal, and K. Brown, "Introduction: Applicant workreadiness and graduate employability challenges in the Asia Pacific," in Transitions from Education to Work, Routledge, 2017, pp. 3-15.

[23] P. Gilding, M. Hogarth, and R. Humphries, "Safe companies: An alternative approach to operationalizing sustainability," Corp. Environ. Strateg., vol. 9, no. 4, pp. 390-397, 2002.
[24] U. Atz, T. Van Holt, E. Douglas, and T. Whelan, "The Return on Sustainability Investment (ROSI): Monetizing financial benefits of Sustainability actions in companies," in Sustainable Consumption and Production, Volume II, Springer, 2021, pp. 303-354.

[25] U. Petschow, J. Rosenau, and E. U. von Weizsäcker, Governance and sustainability: New challenges for states, companies and civil society. Routledge, 2017.

[26] B. TJAHJADI and H. TJARAKA, "The Effect of Good Corporate Governance and Information Transparancy on Corporate Financial Performance in Banking Industries in Indonesia."

[27] H. Malini, "Determinants of Shariah Banking Performances in Indonesia Through the Perspective of Economic and Social Level," $J$. Ekon. Bisnis dan Kewirausahaan, vol. 9, no. 1, pp. 47-57, 2020.

[28] K. Spong, R. J. Sullivan, and R. DeYoung, "What makes a bank efficient? A look at financial characteristics and bank management and ownership structure," Fed. Reserv. Bank Kansas City, Financ. Ind. Perspect. December, pp. 1-19, 1995.

[29] B. Scholtens and S. van't Klooster, "Sustainability and bank risk," Palgrave Commun., vol. 5, no. 1, pp. 1-8, 2019. 